\title{
TANTANGAN DALAM PEMBELAJARAN PERGURUAN TINGGI \\ DAN IMPLEMENTASI MERDEKA BELAJAR DI MASA PANDEMI COVID-19
}

\author{
Endang Kartini. 1), Lalu Mimbar ${ }^{2)}$, Izrawati, ${ }^{3)}$ \\ ${ }^{1), 2)}$ STIE AMM Mataram, ${ }^{3)}$ MTs.Negeri 1 Lombok Barat \\ Emai; endangkartini979@gmail.com
}

\begin{abstract}
Abstrak
Penelitian ini bertujuan untuk mengetahui tantangan pembelaran perguruan tinggi dan Implementasi Merdeka Belajar di Masa Pandemi Covid-19. Metode yang digunakan dalam penelitian ini adalah studi literature atau penelitian kepustakaan. Studi literature dilakukan dengan membaca sumbersumber kepustakaan untuk memperoleh data yang diperlukan Sumber data yang digunakan berasal dari data sekunder, dimana data sekunder tersebut dikumpulkan melalui buku teks, jurnal ilmiah, perodical. Hasil penelitian menunjukkan bahwa Pembelajaran daring adalah pembelajaran yang menggunakan model interaktif berbasis internet dan Learning Manajemen System (LMS) Kemampuan dosen dan mahasiswa dalam pembelajaran daring beragam, ada yang telah terbiasa, tak lepas masih ada juga yang terpaksa dan tidak siap. Namun, kondisi wabah memaksa semuanya harus siap memanfaatkan teknologi informasi untuk mencegah wabah meluas. Pandemi Coronavirus Disease (Covid-19) justru memberikan potensi besar menjadi katalis dalam implementasi kebijakan Merdeka Belajar: Kampus Merdeka. Dosen dan mahasiswa menjadi actor dalam pembelajaran secara mandiri dengan bantuan teknologi informasi. Implementasi pembelajaran daring bukan hanya didominasi Perguruan Tinggi Negeri (PTN), Perguruan Tinggi Swasta (PTS) juga telah mengimplementasikan kuliah daring dengan baik. Misalnya, STIE AMM, yang telah memiliki sarana pembelajaran daring menggunakan platform LMS dengan tampilan dan URL: https://stieamm.ecampuz.com
\end{abstract}

Kata Kunci : Tantangan Dalam Pembelajaran,Implementasi Merdeka Belajar Di Masa Pandemi Covid-19

\section{Abstract}

This study aims to determine the challenges of higher education learning and the implementation of independent learning during the Covid-19 pandemic. The method used in this research is literature study or library research. Literature studies are carried out by reading library sources to obtain the required data. The data sources used are secondary data, where secondary data is collected through textbooks, scientific journals, and perodical. The results showed that online learning is learning that uses an internet-based interactive model and a Learning Management System (LMS). The abilities of lecturers and students in online learning vary, some are accustomed to it, cannot be separated, there are also those who are forced and unprepared. However, the condition of the plague forces everyone to be ready to take advantage of information technology to prevent the outbreak from spreading. The Coronavirus Disease (Covid-19) pandemic has great potential to become a catalyst in the implementation of the Merdeka Learning: Merdeka Campus policy. Lecturers and students become actors in independent learning with the help of information technology. The implementation of online learning is not only dominated by State Universities (PTN), Private Universities (PTS) have also implemented online lectures well. For example, STIEAMM, which already has an online learning facility using an LMS platform with a display and URL: https://stieamm.ecampuz.com The implementation of online learning is not only dominated by State Universities (PTN), Private Universities (PTS) have also implemented lectures online well. For example, STIEAMM, which already has an online learning facility using the LMS platform with display and URL: https://stieamm.ecampuz.com

Keywords: Challenges in Learning, Implementation of Free Learning During the Covid-19 Pandemic 


\section{PENDAHULUAN}

Pandemi Corona Virus Disease (Covid19) menerapa dunia sejak awal tahun 2020 telah berdampak signifikan pada segala aspek kehidupan, termasuk dunia Pendidikan tinggi. Mudahnya penularan virus corona dan dampak kematian tinggi bagi penderitanya telah mengubah pembelajaran tatap muka yang semula mendominasinya, dihentikan sementara dan didesak untuk bermigrasi ke pembelajaran berbasis jaringan internet. Direktorat Jenderal Pendidikan Tinggi (Ditjen Dikti), Kementerian Pendidikan dan Kebudayaan (Kemendikbud) merespon kondisi ini dengan memberikan kemudahan pembelajaran di masa darurat Covid19 kepada mahasiswa di perhuruan tinggi. Tertuang dalam Surat Edaran dari Menteri Pendidikan dan Kebudayaan Nomor 36962/MPK.A/HK/2020 tanggal 17 Marat 2020 tentang Pembelajaran secara Daring dan Bekerja dari Rumah dalam rangka Pencegahan Covid-19. Aturan ini kemudian diperkuat oleh surat tertanggal 31 Maret 2020 ditujukan kepada: 1).Seluruh Pimpinan Perguruan Tinggi Negeri/ Swasta (PTN/PTS), dan 2). Seluruh Kepala Lembaga Layanan Pendidikan Wilayah I sampai dengan XIV. Adapun salah satuisi suratnya mengenai berakhirnya pada semester genap 2019/2020, dapat diperpanjang 1 semester, dan pengaturannya diserahkan kepada Pimpinan Perguruan Tinggi sesuai dengan kondisi dan situasi setempat. Covid-19 sebenarnya mampu mendorong percepatan implementasi Pendidikan jarak jauh bernasiskan teknologi informasi.

Wabah menjadi momentum penting bahwa Pendidikan jarak jauh harus sudah mulai dijajaki secara serius. Berdasarkan survey yang dilakukan Ditjen Dikti, 98 persen perguruan tinggi telah melakukan pembelajaran daring, Mahasiswa menilai pembelajaran daring berjalan cuku pefektif. Pencapaian ini merupakan suatu hal yang luar biasa sekali, mengingat hamper sebelum pandemi. Kemendikbud telah mendorong pemanfaatan teknologi untuk memperkaya pembelajaran, tetapi belum Menurut Pelaksanaan Tugas (PLT) Direktur jenderal (Dirjen) Dikti, belum mencapai hasil optimal. Sedikit sekali perguruan tinggi yang telah melakukan pembelajaran daring, bisa dikatakan wabah pandemic ini seperti berkah terselubung bagi praktik pembelajaran kampus.

Implementasi pembelajaran daring ini menghadapi sejumlah kendala di lapangan. Pertama, dari sisi budaya pembelajaran, masih banyak dosen maupun mahasiswa yang belum terbawa menggunakan system pembelajaran daring. Kondisi ini menggambarkan terjadi kesenjangan digital atau literasi digital. Dosen dan mahasiswa perlu adaptasi keras untuk mampu terampil dalam menggunakan pembelajaran daring. Misalnya, dosen dituntut harus meningkatkan metode pengajarannya agar proses pembelajaran mahasiswa berhenti karena pandemic dan hasil kualitas pembelajaran tidak turun meskipun tanpa tatap muka. Masalah kedua, Pembelajaran daring menghadapi kendala jaringan internet. Indonesia saat ini masih mengalami kendala kesenjangan digital antara wilayah dalam akses internet. Berdasarkan kajian Kemendikbud Pembelajaran daring oleh perguruan tinggi selama masa pandemi Covid-19 menghadapi kendala utama masih soal jaringan internet. Untuk mensiasatinya, Dirjen Dikti berusaha mempersiapkan pembelajaran semester depan dengan lebih baik, melalui kerjasama dengan Kementerian Komunikasi dan Informatika (Kemenkominfo) untuk penyediaan internet di daerah blank sport. Di masa pandemic mahasiswa sudah Kembali kedaerah mereka masing-msing di mana jaringan internet belum merata. Masalah ketiga, belum semua perguruan tinggi memiliki system Pembelajaran daring, baik secara infrastruktur maupun platform pembelajaran. Kemendikbud memiliki berbagai program kegiatan terkait Pendidikan berbasiskan teknologi informasi ini. Kemendikbud berusaha memaksimalkan platform Sistem Pembelajaran Daring (SPADA). Platfortm digital antar perguruan tinggi itu kini telah memiliki 3.000 modul yang bisa dimanfaatkan oleh mahasiswa maupun dosen dalam kegiatan belajar mengajar secara dalam jaringan (daring). Dosen dan mahasiswa dapat mengakses langsung sumber pembelajaran dari pergruan tinggi lain di www,spada.kemendikbud.go.id. Sementara bagi perguruan tinggi dengan keterbatasan sumberdaya pembelajaran daring. Dikti menyediakan 
kuliahdaring.kemendikbud.go.id.

Pemerintah juga bekerjasama berbagai platform swasta menyediakan aplikasi Pembelajaran daring seperti Google, Huawei, Microsoft. Keempat, Pendidikan daring membutuhkan jaringan internet yang sering kali biayanya mahal sehingga memberatkan kalangan mahasiswa. Ditjen Dikti dan berbagai perguruan tinggi mengupayakan pengurangan beban ekonomi mahasiswa untuk mengeluarkan biaya kuota internet tersebut dengan subsidi kuota dan/atau pulsa. Semangat gotong royong sangat terasa, Ketika sejumlah penyedia layanan telekomunikasi seperti Telkom, Indosat, XL, melalui program tanggungjawab perusahaan turut berpartisipasi memberikan akses internet gratis.

Masa pandemi yang belum menentu kapan berakhir menjadi tantangan berat bagi perguruan tinggi ke depan. Kita semua berharap perguruan tinggi mampu adaptif untuk menghasilkan kualitas pembelajaran daring setara seperti layaknya sebelum pandemic menerpa. Mahasiswa menyerap ilmu dengan baik Pembelajaran daring diharapkan tidak serta merta mengorbankan kualitas lulusan. Selain mempercepat pelaksanaan metode Pembelajaran jarak jauh di kampus-kampus Indonesia, pandemic menjadi sebuah ujian dan tantangan konsep Merdeka Belajar Kampus Merdeka. Seluruh sivitas akademika di Indonesia mencoba sebuah konsep pembelajaran yang bersifat mandiri.

Pembelajaran di masa akan dating memungkinkan terbentuk sebuah normal baru di mana akan sangat bergantung pada penggunaan gawai dan layer computer alih-alih tata pmuka. Kita harus mampu menghadapinya.

\section{TELAAH LITERATUR}

Pembelajaran online pertama kali dikenal karena pengaruh dari perkembangan pembelajaran berbasis elektronik (e-learning) yang diperkenalkan oleh Universitas Illionis melalui system pembelajaran berbasis komputer (Hardiayanto). Online learning merupakan suatu sistem yang dapat memfasilitasi siswa belajar lebih luas, lebih banyak, dan bervariasi. Melalui fasilitas yang disediakan oleh system tersebut, siswa dapat belajar kapan dan dimana saja tanpa terbatas oleh jarak, ruang dan waktu. Materi pembelajaran yang dipelajari lebih bervariasi, tidak hanya dalam bentuk verbal, melainkan lebih bervariasi seperti visual, audio, dan gerak. Secara umum, pembelajaran online sangat berbeda dengan pembelajaran secara konvensional.

Pembelajaran online lebih menekankan pada ketelitian dan kejelian siswa dalam menerima dan mengolah informasi yang disajikan secara online. Mengingat online learning sebagai metoda atau saran akomunikasi yang mampu memberikan manfaat besar bagi kepentingan para peneliti, pengajar, dan siswa, maka para pengajar perlu memahami karakteristik atau potensi online learning agar dapat memanfaatkannya secara optimal untuk kepentingan pembelajaran para siswa-nya. Keuntungan online learning adalah media yang menyenangkan, sehingga menimbulkan ketertarikan siswa pada programprogram online Online learning meliputi aspek perangkat keras (infrastruktur) berupa seperangkat komputer yang saling berhubungan satu sama lain dan memiliki kemampuan untuk mengirimkan data, baik berupateks, pesan, grafis, maupun suara.

Dengan kemampuan ini online learning dapat diartikan sebagai suatu jaringan komputer yang saling terkoneksi dengan jaringan computer lainnya keseluruh penjuru dunia (Kitao,1998). Pengertian online learning bukan hanya berkaitan dengan dengan perangkat keras saja, melainkan juga mencakup perangkat lunak berupa data yang dikirim dan disimpan, sewaktu-waktu dapat diakses. Beberapa komputer yang saling berhubungan satu sama lain dapat menciptakan fungsi sharing yang secara sederhana dapat disebut sebagai jaringan (networking). Fungsi sharing yang tercipta melalui jaringan (networking) tidak hanya mencakup fasilitas yang sangat dan sering dibutuhkan, seperti printer atau modem, maupun yang berkaitan dengan data atau program aplikasi tertentu. Online learning secara menyeluruh pun mulai diterapkan dalam dunia 
pendidikan, ketika dunia diterjang pandemi corona. Kebijakan kebijakan pun dilakukan untuk meliburkan seluruh lembaga pendidikan. Hal ini dilakukan sebagai upaya mencegah meluasnya penularan virus corona. Diharapkan dengan seluruh lembaga pendidikan tidak melaksanakan aktivitas seperti biasanya, hal ini dapat meminimalisir menyebarnya penyakit covid 19 ini. Hal serupa juga sudah dilakukan oleh berbagai negara yang terpapar penyakit covid 19 ini,

Kebijakan lockdown atau karantina dilakukan sebagai upaya mengurangi interaksi banyak orang yang dapat member akses pada penyebaran virus corona. Penyebaran virus corona ini pada awalnya sangat berdampak pada dunia ekonomi yang mulai lesu, tetapi kini dampaknya dirasakan juga oleh dunia pendidikan. Kebijakan yang diambil oleh banyak negara termasuk Indonesia dengan meliburkan seluruh aktivitas pendidikan, membuat pemerintah dan lembaga terkait harus menghadirkan alternatif proses pendidikan bagi peserta didik maupun mahasiswa yang tidak bisa melaksanakan proses pendidikan pada lembaga pendidikan.

Berdasarkan data yang diperoleh dari UNESCO, saat ini total ada 39 negara yang menerapkan penutupan sekolah dengan total jumlah pelajar yang terpengaruh mencapai 421.388.462 anak. China sejauh ini memiliki jumlah pelajar yang paling banyak terpengaruh karena virus corona yaitu sekitar lebih dari 233 juta siswa. Sedangkan negara lainnya, hingga 13 Maretada 61 negara di Afrika, Asia, Eropa, Timur Tengah, Amerika Utara dan Amerika Selatan yang telah mengumumkan atau menerapkan pembatasan pembelajaran sekolah dan universitas. UNESCO menyediakan dukungan langsung ke negara-negara, termasuk solusi untuk pembelajaran jarak jauh yang inklusif.

Kebijakan menutup sekolah di negaranegara tersebut, berdampak pada hampir 421,4 juta anak-anak dan remaja di dunia. Negara yang terkena dampak Covid-19 menempatkan respons nasional dalam bentuk platform pembelajaran dan perangkat lain seperti pembelajaran jarak jauh. Dalam situasi UNESCO dikemukakan bahwa pandemi corona ini mengancam 577 juta pelajar di dunia. Sementara UNESCO menyebutkan, total ada 39 negara yang menerapkan penutupan sekolah dengan total jumlah pelajar yang terpengaruh mencapai 421.388 .462 anak. Total jumlah pelajar yang berpotensi berisiko dari pendidikan pra-sekolah dasar hingga menengah atas adalah 577.305.660. Sedangkan jumlah pelajar yang berpotensi berisiko dari pendidikan tinggi sebanyak 86.034.287 orang. (Purwanto, dkk.2020).

Dampak dari adanya COVID-19 menyebabkan perekonomian di Indonesia menjadi merosot, menjatuhkan nilai tukar rupiah, harga barang naik, terutama alat-alat kesehatan. Hal ini juga berdampak pada system pendidikan di Indonesia. Hasil keputusan dari menteri pendidikan bahwa seluruh kegiatan pembelajaran baik di sekolah maupun perguruan tinggi dilaksanakan di rumah masing-masing melalui aplikasi yang tersedia.

Menteri pendidikan mengeluarkan Surat Edaran Nomor 3 Tahun 2O2O Tentang Pencegahan Corona Virus Disease (COVID-19) Pada Satuan Pendidikan yang menyatakan bahwa meliburkan sekolah dan perguruan tinggi. (Kemdikbud RI, 2020). Hal ini dilakukan untuk memutus mata rantai penyebaran COVID-19, sebagai gantinya kegiatan pembelajaran dilakukan secara online untuk semua jenjang pendidikan. (Pratiwi, 2020). Bentuk perkembangan teknologi informasi yang dapat dimanfaatkan sebagai media pembelajaran adalah menggunakan e-learning (pembelajaran online) (Hartanto, 2016).

Pembelajaran online diartikan sebagai suatu jaringan komputer yang saling terkoneksi dengan jaringan computer lainnya ke seluruh penjuru dunia (Kitao, 1998 dalam (Riyana\& Pd, n.d.)). Aplikasi e-learning ini dapat memfasilitasi aktivitas pelatihan dan pembelajaran serta proses belajar mengajar secara formal maupun informal, selain juga memfasilitasi kegiatan dan komunitas pengguna media elektronik, seperti internet, intranet, CD-ROM, Video, DVD, televisi, HP, PDA, dan lain sebagainya (Darmawan, 2012). Dalam penerapan e-learning (pembelajaran 
online), dosen dan mahasiswa memiliki perannya masing-masing. Dosen memiliki peran sebagai fasilitator dan pembimbing dalam kegiatan pembelajaran, sedangkan mahasiswa memiliki peran sebagai konstruktor pengetahuan, pembelajar mandiri (independent learners), dan pemecah masalah (problem solvers) (Bintaro \& Kusir dalam Maudiarti, 2018)

\section{METODE PENELITIAN}

Metode yang digunakan dalam penelitian ini adalah studi literature atau penelitian kepustakaan. Studi literature dilakukan dengan membaca sumber-sumber kepustakaan untuk memperoleh data yang diperlukan (Arikunto, 2013). Sumber data yang digunakan berasal dari data sekunder, dimana data sekunder tersebut dikumpulkan melalui buku teks, jurnal ilmiah, perodical (Nazir, 2014), e-book, website, peraturan perundang-undangan, dan sumber-sumber lain yang relevan dengan masalah penelitian. Data yang dikumpulkan, dianalisis secara kualitatif dengan model Miles and Huberman. Menurut Mile dan Huberman (dalam Sugiyono, 2010), aktivitas dalam analisis data kualitatif dilakukan secara interaktif dan terus menerus sampai tuntas yang digambarkan dalam empat langkah. Empat langkah tersebut meliputi data collecting (pengumpulan data), data reduction (reduksi data), data display (penyajian data), dan conclusion drawing/ verification (penarikan kesimpulan dan verifikasi).

\section{HASIL PENELITIAN DAN PEMBAHASAN}

Pembelajaran daring adalah pembelajaran yang menggunakan model interaktif berbasis internet dan Learning Manajemen System (LMS). Pembelajaran daring merupakan program penyelenggaraan kelas pembelajaran dalam jaringan untuk menjangkau kelompok target yang masif dan luas (Bilfaqih dan Qomaruddin, 2015). Pembelajaran daring merupakan bagian dari pendidikan jarak jauh yang secara khusus menggabungkan teknologi elektronika dan teknologi berbasis internet. Pendekatan moda daring memiliki karateristrik constructivism, social constructivism, community of learners yang inklusif, pembelajaran berbasis komputer, kelas digital, interaktivitas, kemandirian, aksesibilitas, dan pengayaan (Nurhayati, 2020; Fitriyani et al, 2020; Susmiati, 2020; Hignasari, 2020). Pembelajaran daring ini menjadi sebuah pilihan yang tidak terelakkan bagi institusi pendidikan. Di tengah pandemi Covid-19, metode pembelajaran ini dapat menjadi solusi agar proses belajar mengajar dapat tetap berlangsung. Guru tetap bisa mengajar dan peserta didik tetap bisa belajar di rumah selama pandemic ini. Pembelajaran daring identik dengan pemanfaatan fitur teknologi berbasis internet, yang sangat bergantung pada ketersediaan teknologi informasi.

\section{Merdeka Belajar di Masa Pandemi}

Kemampuan dosen dan mahasiswa dalam pembelajaran daring beragam, ada yang telah terbiasa, tak lepas masih ada juga yang terpaksa dan tidak siap. Namun, kondisi wabah memaksa semuanya harus siap memanfaatkan teknologi informasi untuk mencegah wabah meluas. Pandemi Corona virus Disease (Covid-19) justru memberikan potensi besar menjadi katalis dalam implementasi kebijakan Merdeka Belajar: Kampus Merdeka. Dosen dan mahasiswa menjadi actor dalam pembelajaran secara mandiri dengan bantuan teknologi informasi.

\section{Kebijakan Pembelajaran Daring PT Menghadapi COVID-19}

Dampak pandemic telah mendisrupsi proses pembelajaran pendidikan tinggi di Indonesia. Menteri Pendidikan dan Kebudayaan mengeluarkan Surat Edaran pada tanggal 9 Maret 2020 tentang Pembelajaran secara Daring dan Bekerja dari Rumah dalam rangka Pencegahan Penyebaran COVID-19. Semua kampus di Indonesia mau tidak mau mengeluarkan kebijakan mitigasi dampak wabah.

Secara umum, Sekolah Tinggi Ilmu Ekonomi (STIE AMM Mataram) mulai melaksanakan perkuliahan dalam bentuk daring untuk semester Genap 2019/2020 adalah sejak 
pekan ke-7 perkuliahan atau pada tanggal 16 Maret 2020. Melalui Surat Edaran Nomor T/21018/IT2/TU.00.08/2020, Ketua STIE AMM Mataram mengimbau agar perkuliahan dilaksanakan dengan cara daring (daring) menggunakan fasilitas yang telah disediakan seperti aplikasi system manajemen pembelajaran yang terintegrasi yaitu my ITS Classroom.

\section{Praktik Baik Pembelajaran Daring PTS di Masa Pandemi}

Implementasi pembelajaran daring bukan hanya didominasi Perguruan Tinggi Negeri (PTN), Perguruan Tinggi Swasta (PTS) juga telah mengimplementasikan kuliah daring dengan baik. Misalnya, STIEAMM, yang telah memilikisarana pembelajaran daring menggunakan platform LMS dengan tampilan dan URL: https://stieamm.ecampuz.com Fasilitas ini sudah dimanfaatkan oleh sebagian besar dosen dalam memberikan pengajaran kepada mahasiswa. Namun, sarana tersebut masih belum sepenuhnya bisa diterapkan dalam seluruh pertemuan perkuliahan, dikarenakan perekaman video daring tiap dosen hanya baru sempat dilakukan untuk 2 pertemuan dari total 14 pertemuan dalam 1 matakuliah 4 SKS.

Alternatif cara yang dilakukan sebagian besar dosen STIE untuk memberikan perkuliahan adalah menggunakan teknologi Zoom maupun Google Meet. Penggunaan media Zoom maupun Google Meet saat menyampaikan materi kepada mahasiswa bukan berarti tanpa kendala. Seringkali, saat kuliah daring berlangsung, jaringan internet bisa terputus atau sinyal lemah, dan bahkan juga habisnya kuota internet. Teknologi Zoom yang gratis pun memiliki batasan waktu, dan Google Meet juga memiliki batasan dalam jumlah penggunanya.

Tantangan terbesar saat memberikan kuliah secara daring selama kurang lebih tiga bulan lamanya adalah bagaimana mengetahui bahwa materi yang kita sampaikan sudah cukup diterima dan dipahami dengan baik oleh mahasiswa? Hal tersebut tentunya penting untuk diketahui dosen.
Setiap kali selesai perkuliahan secara daring pun, para dosen di STIE wajib memasukkan presensi dan berita acara kedalamformulir yang ada pada system informasi. Sistem tersebut akan merekam setiap pertemuan dalam bentuk isian tentang materi kuliah apa yang telah disampaikan dosen pada hari itu, jumlah mahasiswa yang hadir, bentuk perkuliahan, tugas apa yang disampaikan, dan evaluasi pertemuan yang ada pada hariitu.

\section{SIMPULAN}

Kemampuan dosen dan mahasiswa dalam pembelajaran daring beragam, ada yang telahter biasa, tak lepas masih ada juga yang terpaksa dan tidak siap. Namun, kondisi wabah memaksa semuanya harus siap memanfaatkan teknologi informasi untuk mencegah wabah meluas. Dampak pandemic telah mendisrupsi proses pembelajaran pendidikan tinggi di Indonesia. Menteri Pendidikan dan Kebudayaan mengeluarkan Surat Edaran pada tanggal 9 Maret 2020 tentang Pembelajaran secara Daring dan Bekerja dari Rumah dalam rangka Pencegahan Penyebaran COVID-19. Semua kampus di Indonesia mau tidak mau mengeluarkan kebijakan mitigasi dampak wabah.

Implementasi pembelajaran daring bukan hanya didominasi Perguruan Tinggi Negeri (PTN), Perguruan Tinggi Swasta (PTS) juga telah mengimplementasikan kuliah daring dengan baik. Misalnya, STIEAMM, yang telah memiliki sarana pembelajaran daring menggunakan platform LMS dengan tampilan dan URL: https://stieamm.ecampuz.com Alternatif cara yang dilakukan sebagian besar dosen STIE untuk memberikan perkuliahan adalah menggunakan teknologi Zoom maupun Google Meet. Penggunaan media Zoom maupun Google Meet saat menyampaikan materi kepada mahasiswa bukan berarti tanpa kendala. Seringkali, saat kuliah daring berlangsung, jaringan internet bisa terputus atau sinyal lemah, dan bahkan juga habisnya kuota internet. Teknologi Zoom yang gratis pun memiliki batasan waktu, dan Google Meet juga memiliki batasan dalam jumlah penggunanya. Tantangan terbesar saat memberikan kuliah secara daring selama kurang lebih tiga bulan lamanya adalah 
bagaimana mengetahui bahwa materi yang kita sampaikan sudah cukup diterima dan dipahami dengan baik oleh mahasiswa

Covid-19 adalah sebuah virus yang menyerang system pernafasan manusia. Gejala gejala Covid-19 yaitu antara lain gejala pernapasan seperti deman, sesak napas, dan batuk kering. Pemerintah mengambil tindakan dengan membatasi pergerakan di luar rumah agar memutus rantai penyebaran Covid-19 dilakukan dengan system pembatasan social atau menjaga jarak dengan orang lain, menjauhi perkumpulan, dan menghindari pertemuan massal, dan sebaiknya untuk tetap di rumah saja. Kegiatan pendidikan diliburkan sementara, sebagai pengganti kegiatan pembelajaran tatap muka di alihkan dengan kegiatan pembelajaran secara daring.

\section{DAFTAR PUSTAKA}

Arikunto, Suharsimi. (2013). Prosedur Penelitian: Suatu Pendekatan Praktik. Jakarta: Rineka Cipta

Ali Sadikin, dkk, 2020, Pembelajaran Daring di Tengah Wabah Covid-19 (Online Learning in the Middle of the Covid-19 Pandemi, BIODIK: Jurnal Ilmiah Pendidikan Biologi ISSN 2580-0922 (online), ISSN 2460-2612 (print) Volume 6, Nomor 02, Tahun 2020, Hal. 214-224 Available online at:

Bilfaqih, Yusuf dan Qomaruddin, M. Nur. (2015). Esensi Pengembangan Pembelajaran Daring. Yogyakarta: Deepublish

Dirjen) Dikti,, 2020, Menurut Pelaksanaan Tugas (PLT) Direktur jenderal (Dirjen) Dikti,

Dwi Sulisworo, dkk, 2020, Praktek Pembelajaran Daring Era Covid-19, Penerbit CV.Markumi, Jl.Matrijeron, Kota Yogyakarta 55141

Direktorat Jenderal Pendidikan Tinggi 2020, BUKU PENDIDIKAN TINGGI DI MASA PANDEMI COVID-19 Pembelajaran Perguruan Tinggi dan Implementasi Merdeka Belajar di Masa Pandemi Covid19

Hignasari, L., \& Supriadi, M. (2020). Pengembangan E-Learning dengan Metode
Self Assessment Untuk Meningkatkan Hasil Belajar Matematika Mahasiswa Universitas Mahendradatta. Jurnal Kependidikan: Jurnal Hasil Penelitian dan Kajian Kepustakaan di Bidang Pendidikan, Pengajaran dan Pembelajaran, 6(2), 206219.

doi:https://doi.org/10.33394/jk.v6i2.2476

Hartanto, W. (2016). Penggunaan E-Learning sebagai Media Pembelajaran. Jurnal Pendidikan Ekonomi, .18-1 ,)1(10

Kemdikbud RI. (2020). Edaran Tentang Pencegahan Wabah COVID-19 di Lingkungan Satuan Pendidikan Seluruh Indonesia.

Kementerian Dalam Negeri. (2020). Pedoman Umum Menghadapi Pandemi COVID-19 Bagi Pemerintah Daerah. 1-206. https://doi.org/10.1017/ CBO9781107415324.004.

Kementerian Kesehatan. (2020). Pedoman Pencegahan dan Pengendalian Coronavirus Disease (COVID-19). 3, 1-116.

Kemdikbud RI. (2020). Edaran Tentang Pencegahan Wabah COVID-19 di Lingkungan Satuan Pendidikan Seluruh Indonesia

Kemendikbudm, Surat Edaran dari Menteri Pendidikan dan Kebudayaan Nomor 36962/MPK.A/HK/2020 tanggal 17 Marat 2020 tentang Pembelajaran secara Daring dan Bekerja dari Rumah dalam rangka Pencegahan Covid-19

Keputusan Bersama Menteri Pendidikan dan Kebudayaan, Menteri Agama, Menteri Kesehatan dan Menteri Dalam Negeri No. 01/KB/2021, No. 516 Tahun 2020, No. HK.03.01/Menkes/363/2020, dan No. 440882 tentang Panduan Penyelenggaraan Pembelajaran pada Tahun Ajaran 2020/2021 dan Tahun Akademik 2020/2021 di masa Covid-19

Keputusan Direktur Jenderal Pendidikan Islam Kemenag Nomor 3451 Tahun 2020 tentang Petunjuk Teknis Penyelenggaraan Pembelajaran PAI di Sekolah Pada Masa 
KebiasaanBaru

Maudiarti, Santi. (2018). Penerapan E-Learning di Perguruan Tinggi. Perspektif Ilmu Pendidikan, 32 (1), 53-68.

Mustakim, 2020, Efektivitas Pembelajaran Daring Menggunakan Media Online Selama Pandemi Covid-19 Pada Mata Pelajaran Matematika The Effectiveness Of ELearning Using Online Media During The Covid-19 Pandemic In Mathematics

Nazir, Moh. (2014). Metode Penelitian, Jakarta: Ghalia Indonesia

Nurhayati, E. (2020). Meningkatkan Keaktifan Siswa Dalam Pembelajaran Daring Melalui Media Game Edukasi Quiziz pada Masa Pencegahan Penyebaran Covid-19. Jurnal Paedagogy, 7(3), 145-150. doi:https://doi.org/10.33394/jp.v7i3.2645

Nizam, 2020, Pembelajaran Perguruan Tinggi Dan Implementasi Merdeka Belajar Di Masa Pandemi Covid-19, Penerbit Direktorat Jenderal Pendidikan Tinggi Kementerian Pendidikan dan Kebudayaan RI

Paul Usmany, 2020, Dampak Pandemi Covid-19 Terhadap Proses Pembelajaran Online (Studi Eksploratif Pada Mahasiswa Jurusan Akuntansi Fakultas Ekonomi Dan Bisnis Universitas Pattimura) Jurnal Akuntansi • Vol. 6 No. 1, Hal: 23-38 • Juli 2020

Purwanto,dkk.2020. Studi Eksploratif Dampak Pandemi COVID-19 Terhadap Proses Pembelajaran Online di Sekolah Dasar. Journal of Education, Psychology and counseling.Volume 2 Nomor 1 (2020) ISSN Online : 2716-4446

Pratiwi.2020. Dampak Covid-19 Terhadap Kegiatan Pembelajaran Online Di Sebuah Perguruan Tinggi Kristen Di Indonesia. Perspektif Ilmu Pendidikan. Volume 34 Issue 1 p-ISSN: 1411- 5255 http://doi.org/10.21009/PIP.34 1.1.e-ISSN: 2581-2297

Sugiyono. (2010). Metode Penelitian Kuantitatif, Kualitatif dan R \& D. Bandung: Alfabeta

Sutaryo, 2020, Buku Praktis Penyakit Virus
Corona 19 ( Covid-19)

Siahaan, 2020, Dampak Pandemi Covid-19 Terhadap Dunia Pendidikan, Jurnal Kajian Ilmiah (JKI) e-ISSN: 2597-792X, ISSN: 1410-9794 Edisi Khusus No. 1 (Juli 2020),

Susmiati, E. (2020). Meningkatkan Motivasi Belajar Bahasa Indonesia Melalui Penerapan Model Discovery Learning dan Media Video Dalam Kondisi Pandemi Covid-19 bagi Siswa SMPN 2 Gangga. Jurnal Paedagogy, 7(3), 210-215. doi:https://doi.org/10.33394/jp.v7i3.2732

Taradisa, N, 2020, Kendala Yang Dihadapi Guru Mengajar Daring Pada Masa Pandemi Covid-19 Di Min 5 Banda Aceh, Artikel, 2020

Undang-undang Dasar 1945 Pasal 31 ayat (1)

Undang-undangNomor 20 tahun 2003 tentang Sistem Pendidikan Nasiona

https://www.jpnn.com/news/prof-ojat-guru-tidakakan-tergantikan-dengan-teknologi 